\title{
PROPOSED ILLINOIS LEGISLATION PROVIDING FOR FORECLOSURE OF MORTGAGES BY MEANS OF POWER OF SALE
}

Recent depression experience has created opposition to foreclosure of mortgages by judicial proceedings on the grounds that they are slow and expensive. In Illinois the proposed Real Estate Mortgage Act ${ }^{x}$ seeks to remedy these defects by providing, among other things, ${ }^{2}$ for mortgage foreclosure without court action by means of the exercise of a statutory power of sale. The desirability of such legislation depends on whether it affords a speedy, inexpensive method of foreclosure without endangering the rights of interested parties.

The Illinois bill has the generally accepted advantages of foreclosure under statutory power of sale. First, it is simple. A mortgagee who wishes to foreclose merely delivers to the sheriff (or master) ${ }^{3}$ the mortgage, the evidences of indebtedness which it secures, and a written direction to sell the mortgaged property. The direction to sell contains an itemized statement of the aggregate amount of the indebtedness claimed to be due and a list of interested parties entitled to receive notice of the date of sale by mail. Within five days after the delivery of the papers, the sheriff records the direction to sell, and within ten days after delivery publishes the first of three weekly notices advertising the sale. Within ten days of the first publication, copies of the advertisement must be mailed to interested parties, i.e., the mortgagor, assignees of the mortgage, subsequent encumbrancers, and judgment lienholders who have recorded their interests. The sale is conducted by the sheriff, who applies the proceeds to payment of the debt and any subordinate liens. A certificate of sale is issued to the purchaser, and after the redemption period a deed is issued.

The second advantage of the power of sale provisions of the new Illinois bill is that foreclosure expenses will be reduced. Since the mortgagee can foreclose without court action, he does not have to pay service fees and court costs in most cases. 4 Furthermore, the smaller amount of legal work necessary when

IIIl. S. 320, Art. V (r939).

2 The bill also contains provisions affecting foreclosure by action, redemption rights, rights to rents and possession, receiver's powers, deficiency judgments, trust deeds and trust indentures. Ill. S. 320 (I939).

3 Hereafter, whenever the word "sheriff" is used it includes masters.

${ }_{4}$ Service fees in the average foreclosure action in Chicago run from $\$ \mathrm{I}_{5}$ to $\$ 35$. Court costs average around $\$ 30$; this includes a $\$ \mathbf{5} 5$ filing fee and an average court reporter expense of \$I5. These expenses, however, are eliminated only if the foreclosure under power of sale is carried through without a court action; if the mortgagee has to sue for possession, for a receiver, for a deficiency judgment, or for confirmation of the sale, court costs and service fees will be incurred. Of course any provision for compensating the sheriff for mailing notices of the sale to interested parties will partially offset the saving in service fees.

It may be argued that power of sale reduces foreclosure expense another $\$ 50$ which is the usual cost of reference to a master. This was an expense of foreclosure in almost every suit during the early days of the depression when Chicago court calendars were congested with 
foreclosure is under power of sale may be expected to result in lower attorney's fees. 5 The bill does not provide for sheriff's fees for holding sales under power and it appears that existing fee provisions are inapplicable. ${ }^{6}$ While recording fees and costs of abstracts and opinions of title ${ }^{7}$ seem to be unaffected by the proposed bill, costs of advertising the sale should be less than under the present system since the bill does not require notice by publication to interested parties whose residences cannot be discovered by diligent search and inquiry. ${ }^{8}$

Finally, machinery set up by the new bill is not as time-consuming as that now used in Illinois. Heretofore, foreclosure by action has generally involved a minimum delay of ninety days from the time the action is started until the sale under the court decree. Foreclosure under power of sale will make it possible to hold the sale in forty days.9 Other advantages of foreclosure under

foreclosure actions and judges were unable to hear the evidence in every case. Since the congestion has now been relieved, reference to a master has been eliminated in most cases. Attorneys state that it seldom occurs in downstate foreclosures.

5 Chicago attorneys follow quite closely the Chicago Bar Association schedule. It provides for attorney's fees of 7 per cent on the first $\$ 5,000,5$ per cent on the next $\$ 5, \infty 00$, and 4 per cent on the next $\$ 5,000$. This means a $\$ 35^{\circ}$ attorney fee for a $\$ 5,000$ mortgage. Compare this, however, with the $\$ 125$ attorney fee expense reported by the HOLC for its Illinois foreclosure operations. Russell, HOLC Survey of Foreclosure Operations 22 (1937).

The time spent by an attorney in foreclosing a mortgage by court action may vary considerably. In the average proceeding on a $\$ 5, \infty$ mortgage in which the mortgagor defaults, he spends about twenty hours. Power of sale should eliminate about a third of the work involved in foreclosing by court action.

${ }^{6}$ Failure to provide compensation for the sheriff or master who sells under power reduces foreclosure expense. But this reduction can hardly be attributed to any inherent economy in foreclosing under power of sale since it merely amounts to an arbitrary denial of fees for services which still must be performed. Nothing prevents such a reduction in expenses of court foreclosure if the legislature is willing to take away sheriffs' and masters' fees for conduct of court foreclosures.

Undoubtedly some later provision will set the commission to be received by sheriffs and masters for conducting sales under power. Commissions may be increased in view of the added duties imposed on them in conducting such sales, such as sending notices to interested parties and recording the numerous steps in the proceeding.

7 The HOLC reports an average cost in Illinois of $\$ 47.89$ for securing an opinion of title or an abstract. Discussion with Chicago attorneys reveals that they usually pay around $\$ 75$. The provision in the act, applying to both power of sale and foreclosure by action, that makes it unnecessary to give notice to a judgment creditor who has not recorded his judgment lien will reduce the expense of a search to some extent. $\$ \$ 46$, I 3 . But it is difficult to see how the provision for power of sale will reduce these fees. In the distant future costs of examining titles may be lessened because the documents which it is necessary to investigate in order to determine the validity of a foreclosure will be less bulky than if foreclosure had been by court action.

${ }^{8}$ The cost of notifying parties who could not be personally served with summons is part of foreclosure expense in almost every suit. It accounts for about one-half of the $\$_{3} 0$ spent for advertising.

9 This assumes that the sheriff acts with utmost speed. He can add twenty days to this time, however. The statute does not compel him to start publication of the sale notices until ten 
power of sale have been asserted, such as lower interest rates and easy mortgage credit, but the evidence in support of these claims is speculative and often conflicting. ${ }^{10}$

In the interest of a more complete understanding of the provision for foreclosure under power of sale in the new Real Estate Mortgage Act, ${ }^{\text {II }}$ it is proposed in the remainder of this note to discuss in detail certain aspects of the bill, namely Article V (Sections 4I-53), which provide for notice of the sale, determination of controversies arising in connection with the sale, conduct of the sale, disposition of the proceeds of the sale, and the marketability of a title dependent upon a purchase under the statutory power of sale.

\section{PROVISION FOR NOTICE TO INTERESTED PARTIES}

As indicated above the Illinois bill requires notice to be mailed to the mortgagor, subsequent encumbrancers, and judgment lienholders who have recorded their interests. ${ }^{12}$ Arguments can be made against such a requirement: that in

days after receiving the direction to sell. He can add a second ten days by setting the date of the sale at the maximum of fifty days after the first publication rather than at the minimum of forty days. $\S 48$.

ro Foreclosure expense has little bearing on mortgage interest rates. See Fandbook of the National Conference of the Commissioners on Uniform State Laws and Proceedings 256 (32d Annual Meeting, I922); National Conference of Commissioners on Uniform State Laws, Consideration in Committee of Whole of Proposed Uniform Real Estate Mortgage Act 44 (1938). But high foreclosure costs tend to reduce the quantity of mortgage credit available in a particular area. President's Conference on Home Building and Home Ownership, Home Finance and Taxation 94 (I932).

Ix The Illinois act is applicable only to mortgages executed after the act is passed. $\S 4 \mathrm{r}$. But the draftsman for the Commissioners on Uniform State Laws saw fit to expressly provide that parties to a mortgage already in existence may agree to allow foreclosure by power of sale by means of a written agreement to that effect. Model Power of Sale Mortgage Foreclosure Act (final corrected copy) § 2(r) (I940).

In Illinois the parties could presumably accomplish this result by cancelling the existing mortgage and making a new one containing the authority to foreclose under power of sale. Under both acts the mortgagee would perhaps have to give some consideration for this concession if it is to be binding on the mortgagor.

I2 $\$ \S 46,48,32$. Notice of the sale need not be sent to judgment lienors who have not recorded their interest in a manner specially provided for in the act. $\S \mathbf{3} 3$.

It is possible that even in the absence of a statutory requirement for giving notice the Illinois courts might hold a sale irregular where notice had not been given to the mortgagor. See Barnes v. Freed, 342 Ill. 73, $7_{73}$ N.W. 795 (1930).

Many courts, however, will set aside a sale if it appears that the mortgagee fraudulently attempted to conceal notice of the sale from the mortgagor in order to get the property at a low price. Lipsey v. Cross, 63 S.D. 185, 257 N.W. I25 (1934); Lunde v. Irish, 50 N.D. 312, I95 N.W. 825 (1923).

Statutes in many states do not require notice to the mortgagor or subsequentencumbrancers and lienholders: Ala. Code Ann. (Michie, Supp. x936) c. 321, \$ gor 7; Cal. Civ. Code (Deering, I937) $\$ 2924 \mathrm{~b}$ (provision for notice to creditors if they file a request for it); D. C. Code (rg29) $\S 205$; Mass. Stats. Ann. (1933) c. 244, § r4; Mich. Comp. Laws (r929) § I4427 (posting of notice on premises is required); Minn. Stat. (Mason, I927) $\$ 9604$ (requires service of notice on the actual occupant of the land); Miss. Code Ann. (I930) $\$ 2167$; Mo. Rev. Stat. (I929) 
the ordinary case the mortgagor, knowing of the default, is put on inquiry as to the possibility of a sale; ;3 that subsequent encumbrancers and judgment creditors have no more right to require a prior creditor to give them notice of an intention to realize on his security by sale under power than when property is sold on execution, ${ }^{{ }^{4}}$ and in the great majority of cases they do not bid at the sale or redeem from it; that such a requirement operates to destroy an advantage of foreclosure under power since it requires a careful search of title to determine those who must be notified of the sale, and in addition makes the purchaser's title subject to suits to redeem by parties who through error were not given notice of the sale. ${ }^{15}$ On the other hand, considerations in favor of the notice requirement would seem to outweigh the disadvantages. The requirement, as set out in the bill, protects the mortgagor where the mortgagee dishonestly or negligently attempts to foreclose when in fact a valid defense exists, or when the debtor is not in default. Notice is necessary if the period of redemption is to enable the mortgagor to refinance his mortgage; and, furthermore, notice to

$\S 3076$; N.H. L. 1933, c. 161 , § 3, p. 227; N.C. Code Ann. (Michie, r939) § 687; R.I. Gen. Laws Ann. (1938) c. 442, $\$ 18$; S.D. Code (1939) \& 37.3004; Tenn. Code Ann. (Michie, I938) \& 7793; Tex. Stat. (Vernon, 1936) art. 3810; Va. Code Ann. (Michie, 1936) $§ 5167$; W.Va. Code Ann. (Michie \& Sublett, 1937) § 3707; Wis. Stat. (1937) \$\$ 297.04, 272.3I; Wyo. Rev. Stat. Ann. (Courtright, 1931) $\$ 7 \mathrm{I}-207$.

In certain circumstances, courts have set aside sales under power for failure to notify subsequent encumbrancers or judgment creditors even though the statute regulating foreclosure under power of sale did not require notice to be given them. Cassaday v. Wallace, ro2 Mo. 575, I5 S.W. I38 (r89o); Sandler v. Silk, 292 Mass. 493, I98 N.E. 749 (I935) (where the mortgagee in foreclosing failed to notify an attaching creditor of the sale of the property as part of a scheme to defeat the attaching creditor who had requested notice of any sale, the attaching creditor can sue for damages in tort for wrongful and negligent foreclosure); Levin v. Reliance Co-operative Bank, 16 N.E. (2d) 88 (Mass. 1938) (where a creditor has asked for notice of a sale under power, failure to give notice gives him a cause of action for damages on a negligence theory); Goudy v. Cameron State Bank, 2 S.W. (2d) 97 I (Tex. Civ. App. I927) (where subsequent creditor telephoned the bank which held a first mortgage on the property and was not told that the bank was then proceeding to foreclose under power of sale, this failure to act fairly and tell the creditor of the foreclosure, when coupled with inadequacy of price, justifies setting aside the sale).

See also Bon v. Graves, 2 I6 Mass. 440, ro3 N.E. ro23 (rgr4) (second mortgagee allowed to set aside a sale under powerwhere the first mortgagee in foreclosing failed to give notice of the sale to third parties who had expressed an intention to bid at the sale).

${ }^{x_{3}}$ It seems highly unrealistic to argue that the mortgagor is likely to find out about the sale through the newspaper advertisement of it. Courts have generally allowed sale notices to be published in legal notice publications with circulation as low as 180 and reaching only lawyers and not the members of the general public. Judah v. Pitts, 333 Mo. 301,62 S.W. (2d) 715 (1933); Baldwin v. Brown, I93 Cal. 345, 224 Pac. 462 (I924) (paper circulation of only I80 in a city of 16,000 ); Moss v. Keary, 23 I Mich. 295,204 N.W 93 (I925) (legal notice paper with circulation of 400 in the city of Detroit).

${ }^{24}$ Iil. Rev. Stat. (1939) c. 77, \& 14 .

ss Several authorities think that if actual notice must be given to all interested parties, i.e., the mortgagor, subsequent creditors and lienholders, that much of the inconvenience of foreclosure in equity is retained. Durfee and Doddridge, Redemption from Foreclosure SaleThe Uniform Mortgage Act, 23 Mich. L. Rev. 825 (I925). 
subsequent encumbrancers and creditors is essential if the threat of redemption by them is to be effective in forcing the mortgagee to make an adequate bid for the property..$^{x}$ Notice is also necessary if any of the interested parties is to be able to protect his rights in any surplus arising from the sale.

Since notice to the mortgagor and subsequent encumbrancers is essential, it is important to determine whether these parties are as likely to receive notice of a proceeding to foreclose under power of sale as of a proceeding to foreclose by court action. In addition to requiring advertisement of the sale in a newspaper, the bill requires notice of the sale to be mailed to each interested party. Only the New York statute regulating foreclosure under power of sale has this desirable safeguard. ${ }^{x 7}$ It is true the mortgagee can negligently or fraudulently omit the name of an interested party from the direction to sell, or the sheriff may fail to mail a notice to a party listed in the direction to sell..$^{x 8}$ And it can be said that the bill, by providing a simple method of foreclosure, encourages laymen to conduct foreclosures without the aid of legal advice and thus increases the likelihood that notice will not be mailed to an interested party through error. But if there are any omissions, the interests of the persons who are omitted remain unaffected by the foreclosure. One suggestion can be made, however, with respect to the provision for notice by mail, which is that the bill require notice of the sale to be sent by registered mail, thus providing the sheriff with evidence of the sending and receiving of the notice.99

\section{THE OPPORTUNITY FOR INTERESTED PARTIES TO PRESENT THEIR DEFENSES BEFORE SALE}

An adequate method of foreclosure must give interested parties an opportunity to present defenses to the foreclosure before rather than after the sale is held. Such an opportunity prevents economic waste caused when a sale is

${ }^{16}$ See Redemption from Judicial Sales: A Study of the Illinois Statute, 5 Univ. Chi. L. Rev. 625,627 (I938).

${ }^{7}$ The New York statute requires notice of the sale to be served on the mortgagor and his wife, and a subsequent grantee or mortgagee who has recorded his interest. N.Y. Cons. Laws (McKinney, 1937) c. 52, $\$ 54$ I.

${ }^{18}$ When foreclosure is by court action a subsequent purchaser will be protected if he bought property relying on the record and if the record is regular on its face even though the sheriff made a false return of service on some necessary party. I Reeves, Mortgages and Foreclosures in Illinois 537, 538 (I932). See Rivard v. Gardner, 39 Ill. I 25 (I866); Jones v. Neely, 82 Ill. 7 I (r876); Lancaster v. Snow, I84 Ill. 534, 56 N.E. $8 \mathrm{I}_{3}(\mathrm{rg} 00)$.

When foreclosure is under the power of sale given in the new act, the mortgagor will lose recourse against the property if there is a false statement that notice has been mailed to the mortgagor, provided the courts give effect to $\S 5$ I protecting the purchaser without notice from any defect in the sale.

x9 Undoubtedly mortgagors will sue to set aside sales on the grounds that they did not receive the notice mailed to them, and sympathetic courts are likely to oblige by allowing mortgagors to redeem. This seems unfair where the mortgagor really did receive notice; it will be extremely difficult, however, for the mortgagee to prove this. The registered mail return receipt furnishes an excellent way of settling these controversies and of preventing the perpetration of fraud by the mortgagor. 
held and later set aside, enables the mortgagor to object before the rights of an innocent purchaser intervene, and encourages the bidding by third parties at the sale by assuring them that any purchase is not likely to be set aside. In foreclosure by action, interested parties receive notice of the judicial hearing, at which time objections may be raised before a decree is entered. When foreclosure proceedings are started under power of sale, most states enable a mortgagor to present his defenses by allowing him to enjoin a proposed sale. ${ }^{20}$

The proposed legislation in Tllinois does not mention the right to enjoin; instead, it allows an interested party, including the mortgagor, to bring a summary proceeding to resolve any controversy relating to the sale..$^{2 x}$ It is probable that early Illinois cases $^{22}$ - those decided under the old power of sale provisions-will be persuasive in permitting the mortgagor to use the injunction remedy. If injunctions are granted where the mortgagor has a valid objectionand if courts are not too strict in requiring injunction bonds or tender of the amount admittedly due ${ }^{23}$-it would seem that the mortgagor will have as satisfactory a means of raising objections to a foreclosure as he has when foreclosure is by court action. ${ }^{24}$ The proposed bill does not obviate the danger that injunctions may be granted too freely, thus destroying any advantage to be gained in attempting to foreclose under power of sale. That such a danger is real seems to be evidenced by statutes passed in several states restricting the right to enjoin. ${ }^{25}$ Putting this problem to the courts as it does, the adequacy of the

20 Union Central Life Ins. Co. of Cincinnati v. Thompson, 229 Ala. 433, I57 So. 852 (I934); Gerdes v. Burnham, 78 Minn. 5Ix, 8I N.W. ${ }_{516}$ (Igoo); Soufal v. Griffith, I59 Minn. 252, Ig8 N.W. 807 (1924); Cocke v. Bank of Dawson, r80 Ga. 7r4, r80 S.E. 7 xr (I935).

$2 x \& 8 \mathrm{I}$.

${ }^{22}$ Long v. Pomeroy, 8 N.E. I94 (IIl. S. Ct. I886) (mortgage had been satisfied, so court enjoined sale). See Stevens v. Shannahan, I60Ill. 330, 43 N.E. $35 \circ$ (I896); Ryan v. Newcomb, I25 Ill. 9I, I6 N.E. 887 (I888).

${ }^{23}$ The Illinois statute leaves it to the discretion of the court to determine whether an injunction bond should be required in cases where the suit is not to enjoin enforcement of a judgment. Ill. Rev. Stat. (I939) c. 69, $\$ 9$.

${ }_{4}^{24}$ If the mortgagee disregards an injunction or bill to redeem and makes the sale, the purchaser's title is subject to the decree of the court. Lindley v. Easley, 59 S.W. (2d) 927 (Tex. Civ. App. 1932); Union Central Life Ins. Co. of Cincinnati v. Thompson, 229 Ala. 433, I57 So. 852 (I934); Pattillo v. Tucker, 2 I6 Ala. 572, II3 So. I (I927).

In Ryan v. Newcomb, I25 Ill. 9I, I6 N.E. 878 (I888), an Illinois court held that a sale under power did not bar the mortgagor's right to redeem if the mortgagor, at the time of the sale, had a suit pending which alleged that the mortgagor owed nothing; and that he can redeem even though it turns out that he did owe something at the time of the sale. But see the limitation on this in Stevens v. Shamnahan, I6o Ill. 330, 43 N.E. $35^{\circ}$ (1896).

${ }^{25} \mathrm{In}$ South Dakota an injunction can no longer be obtained in an ex parte hearing. Bargmann v. Mutual Benefit Life Ins. Co., 60 S.D. 255, 244 N.W. 324 (1932). See Johnson v. Wheeler, r74 Md. 53r, r99 Atl. 502 (r938); Tenn. Code Ann. (Michie, I938) § ro535; Md. Ann. Code (Bagby, 1924) art. 66, § I6. The statute promulgated by the Home Owners' Loan Corporation requires the mortgagor seeking to enjoin a sale to put up a $\$ 25^{\circ}$ bond, or to per cent of the mortgage debt, whichever is higher. A New Proposal for a Uniform Real Estate Mortgage Act, 86 U. of Pa. L. Rev. 5I7, 522 (1938). 
bill in this respect depends on a wise exercise of judicial discretion in preventing abuse. It has been suggested that the courts should rely on the penalty of $\operatorname{costs}^{26}$ as a sufficient deterrent to groundless suits and should not require the debtor to give an injunction bond or tender the amount admittedly due. Another possibility would be that if suit for the injunction is brought early enough, a hearing might be held before the sale; if the time is too short for a hearing, the mortgagor could be required to show why he failed to apply for an injunction earlier. ${ }^{27}$

\section{ADVERTISEMENT AND CONDUCT OF THE SALE}

The provisions in the proposed Illinois bill regulating advertisement and conduct of the sale are on the whole satisfactory, yet it seems worth while in this discussion to mention the minor defects which appear to exist. Section 48 , requiring the sheriff to publish notice of the sale, allows the last notice to be published as much as thirty days before the sale is held. Decisions and statutes in several states take what would seem to be the better view that the last notice should be published in the week or ten days immediately preceding the sale, thus attracting more bidders than a notice published long before the sale. ${ }^{28}$ Section 49, specifying in detail the contents of the notice, does not-as would seem desirable on the basis of the experience in other states-require the existence of prior liens and encumbrances to be set forth. ${ }^{29}$

The bill does not provide that the advertisement shall contain the terms of the foreclosure sale, what they shall be, or who shall determine them. ${ }^{30}$ Since the notice of the sale need state only the names of the mortgagor and mortgagee as they appear in the mortgage, it does not have to include the name of an assignee of the mortgage who may be the real party in interest. Inclusion of (1938).

${ }^{26}$ A New Proposal for a Uniform Real Estate Mortgage Act, 86 U. of Pa. L. Rev. 5I7, 522

${ }^{27}$ A Minnesota statute provided for this. Minn. Stat. (Mason, 1927$) \S 9387$.

${ }^{28}$ Crump v. Tucker, I49 Miss. 7 II, II5 So. 397 (I928) (sale more than one week after last publication void); Miss. Code Ann. (1930) § 2167; Mo. Rev. Stat. (1929) §3077 (last insertion not more than one week before the sale); N.Y. Cons. Laws (McKinney, 1937) c. 52, \$ 54I (published for twelve weeks "immediately preceding the day of sale").

29 Misstatement in the advertisement of the sale of the amount of liens prior to the one under which foreclosure is being made will justify setting aside the sale. Grace v. Noel Mill Co., 63 S.W. 246 (Tenn. rgor); Pearson v. Gooch, 69 N.H. 208, 40 Atl. $39 \circ$ (1897). Nor will a purchaser be required to complete the sale if he purchases under a belief that he is getting the property free from prior liens. Fransen v. State, 59 S.D. 432, 240 N.W. 503 (r932). See Sims v. Etheridge, 169 Ga. 400 , 150 S.E. 647 (I929) (purchaser cannot be compelled to complete purchase when advertisement of sale does not call attention to fact that foreclosure is subject to a prior senior lien; also, mortgagee in conducting such a sale must offer the property subject to this lien and not require cash payment of the senior lien by the purchaser).

When foreclosure is by court action, the foreclosure decree usually states the liens or encumbrances to which the sale is subject.

${ }^{30}$ When foreclosure is by action, most courts define the terms of the sale in the foreclosure decree. The sale is usually required to be for cash. 
such a provision would seem to be desirable to provide a further opportunity for the real party in interest to receive notice.

Three provisions in Section 50 regulate the sheriff's conduct of the sale. Here again several suggestions can be made as to minor defects which may raise problems. The first provision requires the mortgaged property to be sold in separate tracts "if it is susceptible of division." This provision seems to require sale of property in small parcels even though it may be more advantageous to the mortgagor to have it sold en masse, although practice under a similar provision in the existing Illinois statute ${ }^{3 r}$ relating to execution sales is to offer for sale first any part of the premises and then the whole. To resolve doubts on this matter it would seem advisable that Section 50 expressly set out details of the practice.

The second provision regulating conduct of the sale allows the sheriff, with the consent of the mortgagee, to adjourn the sale by an oral announcement to this effect. No provision is made requiring readvertisement of the sale should it be adjourned to a distant date. ${ }^{32}$ Finally, by this section the person conducting the sale is permitted to discontinue the sale at the direction of the mortgagee.

One general comment with respect to the provisions relating to publication of notice and conduct of the sale should be made. While the sheriff and mortgagee are given discretion in certain matters, such as adjournment and selection of a newspaper in which to advertise, the bill imposes no penalty for abuse of discretion. For instance, what is to prevent the sheriff from publishing notice of the sale in a newspaper with a small circulation, published in a distant part of the county and having little circulation in the neighborhood of the land? Suit on the sheriff's bond seems inadequate because of the difficulty of showing damages. The same problem exists with respect to the mortgagee's discretion in these matters, e.g., as to adjourning the sale. If the mortgagee influences the sheriff in making his decisions, the bill does not impose upon him a duty of good faith. ${ }^{33}$ Fairness in conduct of the sale could be assured if the Illinois

31 Ill. Rev. Stat. (1939) c. 77, § I2.

${ }^{32}$ The Illinois provisions relating to execution sales would seem to be in point here. The provision dealing with sale of real property on execution does not give the sheriff power to adjourn a sale, but would seem to require readvertisement of the sale if adjourned since it provides that no sale shall be held unless the time and place of the sale has been advertised for three weeks. Ill. Rev. Stat. (1939) c. 77, \& 14.

An early Illinois case required complete readvertising of an adjourned sale under power where the trust deed provided for " $3 \circ$ days" advertisement of the sale. Thornton v. Boyden, 3 IIll. 200 (I863); Griffin v. Marine Co. of Chicago, 52 Ill. 130 (I869).

${ }_{33}$ The act sets the stage for giving the mortgagee substantial influence over the sheriff or master in the conduct of the sale. It provides that a mortgagee can give the direction to sell to a sheriff or master. $\S 47$. This enables the mortgagee to pick the person who will hold the sale. As the act now stands no provision is made for compensating the sheriff for conducting a sale under power; it is likely that some provision will later be made for this. When compensation is provided for holding sales, it is likely that sheriffs and masters will be anxious to 
courts would disregard statements in early cases ${ }^{34}$ and set aside sales for any irregularity even though it has not caused damage.

\section{APPLICATION OF THE PROCEEDS OF THE SAIE; DEFICIENCY DECREES}

By Section $5^{2}$ of the bill the sheriff is directed to cancel the evidences of indebtedness and mortgage if the debt is paid, and to apply proceeds of the sale, first to the payment of sale costs, and then to the payment of the mortgaged indebtedness and any subordinate liens. The section would seem to be open, however, to two constructions with regard to the sheriff's duty to pay any subordinate lien upon the property sold. One construction would be that the sheriff hold the proceeds of the sale for thirty days and pay it to the mortgagor unless a subsequent encumbrancer seeks to enforce a proper claim. This construction would not seem unduly harsh since subsequent encumbrancers and lienholders have received notice of the sale, and, therefore, notice of the possibility that there might be a surplus. At any event, following this construction, if any controversy arises over the amount or priority of any lien, or if the sheriff is uncertain how to apply the money, the parties may settle the controversy by means of a summary proceeding. ${ }^{35}$

A different construction would be that the sheriff has an affirmative duty to determine whether subsequent encumbrances exist when no one has asserted a claim. This construction seems to be supported by the mandatory language

hold sales and will be eager to follow the mortgagee's advice in determining matters within his discretion.

In other states where the mortgagee conducts the sale high standards of fairness and reasonableness are set for him. Lange v. MacIntosh, 340 Mo. 247, roo S.W. (2d) 457 (1937) (trustee under trust deed, seeing property is being sold for mere tithe of its value, has a duty to adjourn the sale and await more auspicious circumstances); Carilla v. Hersey, I 2 N.E. (2d) 68 (Mass. 1937) (adjournment was not a violation of the mortgagee's duty of good faith and diligence); Guels v. Stark, 264 S.W. 693 (Mo. I924) (where mortgagee makes an error in advertising a sale, and where in attempting to remedy the error by an oral announcement at the sale he deters bidders, he should postpone the sale); Tedlock v. Torbert, 89 Okla. 218, 2I5 Pac. I96 (1923) (sale set aside where conducted in an ambiguous manner so that purchasers did not know whether they were taking subject to tax liens); Borth v. Proctor, 2rg S.W. 72 (Mo. IgIg) (sale set aside where seller knew someone was interested in buying the property yet sold it exactly at one o'clock as advertised, although the other party arrived a minute later). See Kavolsky v. Kaufman, 273 Mass. 4I8, I73 N.E. 499 (I930) (failure by mortgagee to change terms of a sale when he sees that it deters bidders shows lack of fairness in conducting the sale); Chartrand v. Newton, 296 Mass. 3 I 7, 5 N.E. (2d) 42 (r936); Wheeler v. Slocinski, 82 N.H. 2II, I3I Atl. 598 (I926).

Since in actuality the mortgagee will control sales under power in Illinois through his influence over the sheriff or master, ultimate responsibility for fair conduct of the sale should be placed on him. Only if this is done will fair conduct of sales be assured. See Fransen v. State, 59 S.D. 432,240 N.W. 503 (1932).

34 Cases cited in note 46 infra.

35 Section $8 \mathrm{I}$ provides that in case any controversy arises as to the existence or amount of any lien upon or interest in the property sold, any person whose rights are affected by such controversy, including the officer who is making the sale if his rights and duties are involved, may have the controversy determined in a summary proceeding. 
of Section $5^{2.3^{3}}$ Moreover, the bill directs the sheriff to apply the residue "to the payment in order of priority, of any liens .... which were subordinate to the mortgage." This provision seems to include judgment lienors who have not recorded their interest as provided in Section I3 of the bill, and who, therefore, will not have received notice of the sale. Suppose further that the sheriff applies to the court for determination of this issue, as the statute allows him to do, and suppose no one answers the suit, does the court investigate the amount and priority of the claims without any parties before it, or is the money simply turned over to the mortgagor?

Such a construction of Section 52, placing on the sheriff additional burdens, seems undesirable and perhaps unlikely, although, it is submitted, the problem exists. ${ }^{37}$ The ambiguous character of the section could perhaps be avoided if the bill contained the provision adopted by the draftsman for the Commissioners on Uniform State Laws, which states that the sheriff shall retain the surplus for thirty days and then pay it to the owner of the equity of redemption unless prevented by an order of court or garnishment..$^{8}$

No provision is made in the bill for the mortgagee to collect attorney fees out of the sale proceeds. When foreclosure is by action, the court will add to the decree the sum agreed upon by the parties, or fix a reasonable fee itself, as compensation for the mortgagee's attorney. ${ }^{39}$ Under the act attorney fees cannot be deducted from the sale proceeds, unless the courts allow the parties to contract that the mortgagee's attorney expense shall constitute part of the "costs of the sale" or of the "mortgage indebtedness." A further difficulty arises that if this is allowed, there is no restraint on excessive fees, ${ }^{40}$ nor does the act keep a mortgagee from padding the bill for costs of the sale. ${ }^{4 \mathrm{I}}$

The mortgagee who forecloses under power of sale can, under Section III

${ }^{36}$ The section provides that the sheriff "shall" apply the proceeds to the payment of subordinate liens in the order of their priority.

${ }^{37}$ If the sheriff must apply the surplus arising on the sale to any subordinate lien even though the lienor does not make application for payment, it would seem necessary for the sheriff to employ an attorney to discover liens-a burdensome task, especially if it includes a search of the judgment rolls.

${ }^{38}$ Miodel Power of Sale Mortgage Foreclosure Act (final corrected copy) $\S 6$ (I940).

392 Reeves, Mortgages and Foreclosures in Tllinois $\$ \S 596-603$ ( $\mathrm{r}_{932}$ ).

${ }^{40}$ Some statutes provide that the mortgagee is entitled to add to the mortgage indebtedness an attorney's fee. Usually the statute restricts the amount that can be so deducted from the sale proceeds. See, e.g., Mich. Comp. Laws (I929) $\S$ I 4445 ( $\$ 500$ or less, $\$ 15$ fee; all sums over $\$ 500$ and not exceeding $\$ 1,000, \$ 25$ fee; all sums over $\$ 1,000$, a $\$ 35$ fee; these sums can be included as part of the costs and added on to the amount bid at the sale).

${ }_{4 \pi}$ To safeguard mortgagors from this type of oppression, the Minnesota statute provides that within ten days after a sale, the mortgagee must file an affdavit of a detailed bill of costs and disbursements including attorney's fees. Minn. Stat. (Mason, I927) $\$ 9620$. Within one year, the mortgagor may sue and recover three times the amount of any sums charged as costs or disbursements but not absolutely paid. Minn. Stat. (Mason, r927) \& 9621. For failure to file the affidavit in ten days, the mortgagee must return to the mortgagor any sums retained out of the sale proceeds for printing expense or attorney's fees. Johnson v. Northwestern Loan and Building Co., 60 Minn. 393, 62 N.W. 38 I (1895). That the overcharge was made in 
of the bill, obtain a deficiency decree in a suit to confirm the sale. The mortgagor, however, is given the right to claim as a credit the fair value of the property where the mortgagee, and not an outsider, bought at the sale. The decree obtained in such a suit can be used to support a levy of execution. By making the claim for a deficiency an incident of a suit to confirm, the deficiency action seems to become an equitable one so that the issue of fair market value does not have to be submitted to a jury. If the bill had provided merely for the right to sue for a deficiency it could have been argued that this remedy was in its nature an action at law in which the mortgagor was entitled to a jury trial of the value issue. Jury valuation might mean, insofar as juries are sympathetic to debtors, that no deficiency could be obtained if foreclosure were made by means of power of sale.

\section{MARKETABILITY OF TITLE OBTAINED AT A FORECLOSURE UNDER POWER}

When a foreclosure proceeding under power is strictly in accordance with the proposed act, it is, by Section $5 \mathrm{I}$, to be given the same effect as a sale made pursuant to a decree in a foreclosure suit in which the court had jurisdiction of the subject matter and of the parties. Since the mortgagor is given notice of the proceedings to foreclose and a right to have any controversy determined by a summary action before the sale, it would seem to follow that the purchaser at the sale is protected against any subsequent raising of defenses to the mortgage, e.g., failure of consideration, by the mortgagor..$^{42}$ This construction, however, raises the question whether the notice of the sale may be considered adequate to make it clear to the mortgagor that he can object to the enforceability of the mortgage only before the sale. This doubt could be easily resolved by stating in the notice that the sale would cut off his defenses to the mortgage unless objection were made beforehand.

When foreclosure under power is not in accordance with the provisions in the act, Section $5^{\mathrm{I}}$ provides that no irregularity shall affect the validity of the sale as to any person not having notice of the defect. In view of the construction placed on a similar provision in the Illinois statute relating to execution sales, perhaps the courts will set aside a sale if the purchaser had notice of the irregularity relied upon. ${ }^{43}$ However, a study of the cases decided under

good faith is no defense in an action for triple damages. Hobe v. Swift, 58 Minn. 84, 59 N.W. 83 I ( 1894 ). But failure to file the affidavit does not affect the validity of the sale. Johnson v. Cocks, 37 Minn. $53^{\circ}$ (I887).

${ }^{42}$ Such a construction would be desirable from the point of view of making titles derived from foreclosures under power of sale equally secure as those obtained in a foreclosure action. In practice this rule is no harsher than that applied in foreclosure actions where the mortgagor is required to raise his defenses to the foreclosure at the judicial hearing or else be barred. Fuhrmann v. Fanroth, 254 N.Y. 479, I73 N.E. 685 (x930); Stewart v. Phoenix Nat'l Bank, 49 Ariz. 34, 64 P. (2d) ror (1937).

${ }_{43}$ The provision on execution sales first imposes a $\$ 50$ penalty on an officer who fails to follow the statutory regulations governing sales on execution; it then provides "nor shall any irregularity on the part of the sheriff or other officer having the execution, be deemed to affect 
the execution sale provision is not helpful in solving the further problem of what irregularities will be held to justify setting aside a sale under power.

Other jurisdictions have adopted one of two solutions. Some courts hesitate to set aside a sale for mere irregularities which have not caused damage, arguing that there has been substantial compliance with the statute and that the defect is not prejudicial or misleading. ${ }^{44}$ Other courts, however, set aside a sale for any non-compliance with the statute. $4^{5}$ While the first view avoids the waste involved in reselling property where there has been no substantial injury, it has the disadvantage of removing the only sanction insuring compliance with the statutory regulations and thus gives only a directory effect to the statute. Early Mllinois decisions dealing with sales under power indicate a tendency to favor this view..$^{6}$ The second view results in economic waste when a second sale is required merely to punish the mortgagee for failure to comply with the statute. Provision in Section 5I of the new bill that sale under power shall have the "same effect" as sales pursuant to a court decree might influence Tllinois courts to follow this second view.47 Furthermore, the difficulty of proving actual damage or prejudice to have resulted from a particular omission, it is submitted, makes the strict attitude necessary if the provisions of the act are to be effectively enforced.

Section 5 I, as has been noted above, states that "irregularities in connection with the sale shall [not] affect the validity of the sale." Section 45 of the bill describes three requisites to a sale as "conditions" in the absence of which no

the validity of the sale made under it unless it shall be made to appear that the purchaser had notice." IIl. Rev. Stat. (1939) c. 77, \& 15 . The courts set aside such sales for irregularities where the purchaser has notice. Barnes v. Freed, 342 Ill. 73, I73 N.E. 795 (1930); Weaver v. Peasley \& Co., I63 IIl. 25I, 45 N.E. $x$ I9 (1896).

${ }_{44}$ Reading v. Waterman, 46 Mich. I07, 8 N.W. 69I (I88I); Lau v. Scribner, I97 Mich. $4{ }_{5}$, r6 $_{3}$ N.W. $9{ }_{4}$ (I9I7); Clark v. Duvall, 6r Colo. 76, I 56 Pac. I44 (IgI6); Powers v. Kueckhoff, 4 I Mo. 425 (1867). See 2 Minn. L. Rev. 157 (IgI8).

${ }_{45}$ Wilkinson v. Federal Land Bank of New Orleans, I68 Miss. 645, I50 So. 218 (I933); Gillette v. Abrahams, 42 S.D. 316 , I74 N.W. 745 (1919); Clifford v. Tomlinson, 62 Minn. I95, 64 N.W. 38 I (I895).

${ }^{46}$ Ritchie v. Judd, ${ }^{3} 37$ Ill. 453,27 N.E. 682 (I8gr) (one ground for refusing to set aside a sale where publication of notices had been irregular was that the mortgagor did not show that anyone was misled by the defective notice); Kerfoot v. Billings, I60 Ill. 563, 43 N.E. 804 (1896) (overstatement of the amount of the indebtedness did not operate to justify setting aside a sale under power where it did not deter bidders); Hoyt v. Pawtucket Institute for Savings, IIO Ill. $39 \circ$ ( 1884 ) (notice failed to state the precise amount due, but did state it "substantially"); Fairman v. Peck, 87 IIl. 156 ( 1877 ) (overstatement of indebtedness and sale of property en masse do not justify setting aside a sale under power where no prejudice or injury is shown); Williamson v. Stone, 128 Ill. $x 29,22$ N.E. 1005 (1889) (sale will be set aside if there is unfairness, intentional or unintentional, resulting in injury to the debtor).

${ }_{47}$ See Quick v. Collins, I97 Ill. 39r, 64 N.E. 288 (1902) (where court held it error for the lower court to confirm a sale not in compliance with its decree ordering sale in a partition proceedings, stating that where objection is urged on the fling of the master's report before confirmation, the sale should not be approved unless in accordance with the decree). But see Illinois Midwest Stock Land Bank v. McMahon, 249 Ill. App. 555 (I928); Springer v. Law, I85 Ill. 542,57 N.E. 435 (1900). 
sale shall be made. $4^{8}$ The question arises, then, whether Section $5^{\text {I }}$ protects a purchaser without notice if one of the "conditions," e.g., that the mortgage indebtedness has become due, is absent. Decisions in Illinois and other states have stressed the distinction between mere "irregularities" against which a purchaser in good faith is protected, and "conditions," the absence of which makes the sale absolutely null and void even as to a bona fide purchaser. 49 If the absence of any of these conditions is held to make the sale void even as to a subsequent remote purchaser, the security of titles derived from sales under power is weakened to the point of making it dangerous to foreclose or purchase at such a sale. Strong arguments, however, can be advanced against distinguishing irregularities from conditions. It is not likely that the drafters of the Illinois bill intended Section 45 , dealing with conditions, to be the basis of such a distinction, because one of the purposes of Section $5 \mathrm{I}$ is to protect the purchaser without notice..$^{50}$ Section ${ }_{5}$ I itself provides by implication that one of the conditions-that notice of the sale shall be given-does not make the sale invalid as to a purchaser without notice. It seems, therefore, that the subsequent purchaser is protected even though one of the other two conditions set forth in Section 45 for a sale may be absent.

Another problem raised by this provision of the bill protecting a "purchaser without notice of the irregularity" is the meaning of the words "without notice." If the mortgagee purchases at the sale it seems unlikely that the court will regard him as a purchaser without notice, even though he may not know of the particular irregularity relied upon in the suit to set aside the sale. The provision protecting the purchaser without notice is copied from the Illinois statute relating to execution sales, and, in construing that act, the courts have held that the judgment debtor who purchases on execution is charged with

$4^{8}$ Section 45 reads: "Conditions. No sale shall be made unless ( $\mathrm{I}$ ) the mortgage has been recorded, (2) the entire mortgage indebtedness has become due, whether by acceleration or otherwise, and (3) notice of sale shall have been given as hereinafter provided."

49 Bausman v. Kelley, 38 Minn. I97, 36 N.W. 333 (I888) (sale absolutely void and of no effect, where person purporting to act as attorney of the mortgagor foreclosed a mortgage under power of sale, even though the records were "fair" on their face, and though subsequent remote parties had possession of the property at the time of the suit); Rogers v. Barnes, I69 Mass. I79, 47 N.E. 602 ( 1897 ) (where property was sold under power of sale when interest was not in default); Redmond v. Packenham, 66 Ill. 434 (I872) (mortgage debt had been paid when land was sold under power to a third person). See Fairman v. Peck, 87 Ill. 156 (I877); Lycoming Ins. Co. v. Jackson, 83 Ill. 302 (1876); Cameron v. Irwin, 5 Hill (N.Y.) 272 (I843); Chace v. Morse, 189 Mass. 559 (I905); Shippen v. Whittier, $x 17$ Ill. 282,7 N.E. 642 (I886). But see Butler Bldg. \& Investment Co. v. Dunsworth, I46 Mo. 36r, 48 S.W. 449 (r8g8) (sale to a purchaser in good faith was held valid although mortgage was not in default at the time of the sale under power); Chicago R.I. \& P.R. Co. v. Kennedy, 70 Ill. $35^{\circ}$ (I873) .

${ }^{50}$ Statutes in several states have provisions similar to $\S 45$ of the Illinois bill. Mich. Comp. Laws (I929) § I4426 (this statute lists the following as "prerequisites" for the exercise of a power of sale: default in the mortgage, no suit pending at law on the mortgage, mortgage and all assignments duly recorded); Minn. Stat. (Mason, x927) § 0603 ; Wyo. Rev. Stat. Ann. (Courtright, I93I) § 7I-206; S.D. Code Ann. (I939) § 37.3002; Wis. Stat. (I939) § 297.02; N.Y. Cons. Laws (McKinney, 1937) c. 52, \& 540. None of the decisions construing these sections has made a distinction between the effect of these "requisites" and an ordinary "irregularity" in the title. 
notice of all defects in the sale and thus cannot occupy the position of a purchaser without notice.sI

There is even some doubt whether a disinterested third party, not the mortgagee, who purchases at the sale will be protected by the act. Early Mllinois decisions involving sales under power held that the immediate purchaser at the sale was "charged" with notice of all defects and irregularities in the sale.52 Since the provision in the proposed bill is patterned after the statute relating to execution sales, decisions construing this act might be followed, and an outsider protected from suit to set aside the sale when he has no knowledge of the defect. But even the cases decided under the execution sale statute go far in charging the purchaser at the sale with constructive notice..$^{53}$

The bill is adequate to protect subsequent remote purchasers of property which has at some time been foreclosed under power of sale. The few decisions in Illinois and other states dealing with such cases indicate a tendency to favor the remote purchaser even in doubtful cases. 54 In many jurisdictions subsequent remote purchasers are aided in proving their titles by statutory provisions making the certificate of sale prima facie evidence of a regular foreclosure. 55 The Illinois proposal does not contain such a provision, but requires the sheriff

st King v. Cushman, 4I Ill. 3I (I866). The court might also find support in early Illinois cases dealing with foreclosures under power of sale where it was held that anyone purchasing directly at the sale is charged with notice of the defects in the proceedings. Cassell v. Ross, 33 Ill. 244 (1864). See Gunnell v. Cockerill, 84 Ill. 3I9 (I876); Hamilton v. Lubukee, 5 Ill. 4I5 (I869). For similar decisions in other states see Martini v. Emery, 39 R.I. 463, 98 Atl. 52 (I916); Hinton v. Hall, I66 N.C. 477,82 S.E. 847 (I9x4).

52 Cassell v. Ross, 33 IIl. 244 (I864). See Ritchie v. Judd, I37 Ill. 453,27 N.E. 682 (I89I); Gunnell v. Cockerill, 84 Ill. 319 ( 1876$)$.

$53 \mathrm{McDaniel}$ v. Wetzel, 264 Ill. 212, I06 N.E. 209 (I9I4) (no evidence that the third party purchasing at the sale knew that the notices had not been posted, but the provision relating to purchasers without notice at execution sales does not mean that a sale may not be set aside on account of irregularities coupled with gross inadequacy of price). See Logar v. O'Brien, 339 Ill. 628, I7 I N.E. 629 (I930); Smith v. Huntoon, I34 Ill. 24, 24 N.E. 97 I (I890); Morris v. Robey, 73 Ill. 462 (I874); Barnes v. Freed, 342 Ill. 73, I73 N.E. 795 (I930). But see McGowan v. Goldberg, 28x III. 547, xI7 N.E. IO45 (I9x7); Osgood v. Blackmore, 59 Ill. 26I $(187 \mathrm{x})$.

54 Wilson v. South Park Com'rs, 70 Ill. 46 ( 1873 ); Munn v. Burges, 70 Ill. 604 (I873); Rideout v. Burkhardt, 255 Mo. II6, I64 S.W. 506 (1914); Eubanks v. Brecton, I58 N.C. 230, 73 S.E. roog (I912); Phipps v. Wyatt, I99 N.C. 727 , I55 S.E. 721 (1930); Hinton v. Hall, I66 N.C. 477,82 S.E. 847 (I9I4). See Gunnell v. Cockerill, 84 Ill. 3 I9 (I876); Hamilton v. Lubukee, $5 \mathrm{I}$ Ill. 4 I 5 (I869). But see those cases where the purchaser is charged with notice of the mortgagor's interests if the latter is in possession of the property at the time of the purchase. Clevinger v. Ross, Iog Ill. 349 (I884); Logar v. O'Brien, 339 Ill. 628, I7 I N.E. 629 (r930) (dealing with an execution sale); Barnes v. Freed, 342 Ill. 73, 173 N.E. 795 (1930) (dealing with an execution sale).

55 Cal. Civ. Code (Deering, I937) § 2924b; Mich. Comp. Laws (I929) §§ I4439, I444I; Minn. Stat. (Mason, I927) $\$ \S 9678$, 9622 ; Mo. Rev. Stat. (r929) § 3094 ; N.H. Pub. Laws (I926) c. $215, \S 24 ;$ N.Y. Cons. Laws (McKinney, I937) c. 52, $\$ \S 549^{-5}$ I; Va. Code Ann. (Michie \& Sublett, 1936) \&6r96; Wis. Stat. (r939) \$\$ 297.I6, 297.I7.

The absence of a statutory provision making certain things prima facie evidence of a valid sale has not prevented courts from doing the same thing by decision. Atkinson v. Washington and Jefferson College, 54 W.Va. 32, 46 S.E. 253 (Igo3); Jones v. Frank, I23 Miss. 280, 85 So. 3ro (I920); Smith v. Allbright, 26I S.W. 46r (Tex. Civ. App. r924). 
to record evidence of completion of various steps in the foreclosure..$^{56}$ The recorded copy of the certificate containing notice of sale and of the facts respecting publication and mailing are made "evidence" of the facts stated therein. The officer conducting the sale is also required to record a duplicate of the certificate of sale within three days after the sale. This certificate and the duplicate of it are made evidence of the facts stated therein. ${ }^{57}$

Security of title obtained on foreclosure under power of sale will probably be furthered by judicial application of the doctrines of estoppel and laches..$^{58}$ In several states added protection to title is provided by statutes specially limiting the time in which suits can be brought to set aside sales under power. 59 In one state, however, such a provision has been held unconstitutional as to parties in possession, ${ }^{60}$ and Illinois decisions ${ }^{6 \mathrm{x}}$ dealing with a similar problem

${ }^{56} \S 47$ (requires the sheriff to record a copy of the direction to seli); $\S 48$ (requires the sheriff within three days after the sale to file for record a certificate setting forth a copy of the notice of the sale and certificate respecting the publication and mailing thereof; such certificate is made evidence of the facts stated in it).

$57 \S 75$.

${ }^{88}$ Kerfoot v. Billings, I60 Ill. 563, 43 N.E. 804 (I896); Gibbons v. Hoag, 95 Ill. 45 (I880); McHany v. Schenk, 88 Ill. 357 ( 1878 ); Chace v. Morse, I89 Mass. 559, 76 N.E. I42 (I905); Fox v. Jacobs, 289 Mich. 619, 286 N.W. 854 (I939); Debnam v. Watkins, I78 N.C. 238, 100 S.E. 336 (I9I9); Shelby v. Bowden, I6 S.D. 53I, 94 N.W. 4 I6 (I903); Northwestern Mortgage Trust Co. v. Bradley, 9 S.D. 495, 70 N.W. 648 (I897).

But in the following cases the courts held there were no grounds for applying the doctrines of laches or estoppel: Richards v. Finnegan, 45 Minn. 208, 47 N.W. 788 (r89I); Sheasgreen Holding Co. v. Dworsky, I8I Minn. 79, 23 I N.W. 395 (I930); Walker v. Carleton, 97 Ill. 582 (I88I); Hammon v. Hatfield, I92 Minn. 259, 256 N.W. 94 (I934); Nelson v. Johnson, I67 Minn. 430,209 N.W. 320 (1926).

According to one court laches cannot bar a sale that is absolutely void for lack of some essential condition. Moore v. Dick, I87 Mass. 207, 72 N.E. 967 (Ig05).

59 Minn. Stat. (Mason, I927) §9623; Miss L. (x934) c. 250; Tenn. Code Ann. (Michie, I938) $\S \S 7799,7800$.

The Uniform Mortgage Foreclosure Act allows suit to set aside a sale under power to be brought before expiration of the period of redemption. Model Power of Sale Mortgage Foreclosure Act (final corrected copy) $\$ 8$ ( $\mathrm{I}$ ). But no such proceeding to set aside the sale, directly or collaterally, shall be commenced after the expiration of the period of redemption. Ibid., $\S 8(2)$.

${ }^{60}$ In Hammon v. Hatfield, I92 Minn. 259, 256 N.W. 94 (I934), the mortgagor knew of the intention to sell a month before the sale but was not served with notice of the sale as required by statute. The court held that the statute requiring the mortgagor to sue to set aside a sale with due diligence cannot compel one legally in possession to proceed at law when he is already in complete enjoyment of all he claims; the statute was held unconstitutional insofar as it requires one rightfully in possession of the land to bring an action within a specified time to declare invalid a proceeding to foreclose a mortgage.

Earlier decisions restricted the effect of the statute, holding that it did not apply where the foreclosure was wholly without authority and void, Bausman v. Kelley, $38 \mathrm{Minn}$. I97, 36 N.W. 333 (1888), or where there was a failure to record the mortgage and assignments of it as required by the statute, Burke v. Backus, 5 I Minn. I74, 53 N.W. $45^{8}$ (I892).

6r Although the Torrens Act provides that the registration decree shall be binding and conclusive on all parties, and that any person having any interest in the land who was not actually 
in the Torrens Act registration cases seem to indicate that any attempt to set a fixed time limit for bringing suit to set aside a sale under power would not be enforced.

A final provision of the act dealing with security of title is Section $53{ }^{62}$ which allows the mortgagee to obtain judicial confirmation of the sale. What effect confirmation has upon the title derived from the sale is not made clear by the bill. Section 53 expressly states that the sale is valid and fully effective without confirmation, yet in the following sentence the drafter seems to imply that the section has special efficacy in barring as to all persons the equitable right to redeem. If the decisions construing the effect of confirmation of sales under court decrees are followed, the effect will be slight. ${ }^{63}$ A similar provision in another state has not as yet been construed to have any marked effect in protecting title from suits to set aside..$^{64}$ The conclusion would seem to be that the provision for confirmation is useless.

served with process or notified of the filing of the application may file an answer to the application within two years after entry of the decree and noc afterward, Ill. Rev. Stat. (r939) c. 30, $\$ 70$, the court held in Sheaff v. Spindler, 339 Ill. 540, I7 N.E. 632 (I930), that this did not prevent an adverse claimant who was not made a party from later suing to remove as a cloud on his title the registration decree. See also People ex rel. Kern v. Chase, 165 Ill. 527, 46 N.E. 454 ( 1897 ).

${ }^{62}$ Section 53 reads as follows: "Confirmation of Sale. Courts of chancery shall have jurisdiction .... to confirm ... . any foreclosure sale made as aforesaid under a power of sale contained in a mortgage, but this shall not be construed to mean that a confirmation must be had in order that such sale may be valid and fully effective. In any such suit it shall not be necessary, for the purpose of confirming the foreclosure sale and barring as to all persons the equitable right to redeem from the mortgage, to make as party to the suit any person....."

${ }_{6}$ In Illinois, the judicial confirmation of sales under foreclosure decrees does not have a great effect in preventing the mortgagor or some other party from raising objections based on irregularities in the sale. Grundy County Nat'l Bank v. Sanford, 28I Ill. App. 464 (I935) (aIthough the sale was confirmed, the court will set it aside where the master advertised the sale for one date in some notices and for another date in others; there was no showing of prejudice arising from this defect); see Mlinois Midwest Stock Land Bank v. McMahon, 249 Ill. App. 555 ( 1928 ) (court refuses to set aside the sale after confirmation, but states that confirmation cures any irregularities resulting from departure by the sheriff from the court decree if the court had power to direct such action in the first instance). If the Illinois Midwest Stock Land Bank decision is applied to foreclosures under power of sale, no irregularity in the sale could be cured by the confirmation since the court has no power to dispense with the statutory requirements regulating foreclosure under power of sale. See also Garrett v. Moss, 20 Ill. 549 (1858); Fergus v. Woodworth, 44 Ill. 374 (I867); Gross v. Parker, $x_{37}$ Ill. App. $3^{\text {I } 3}$ (1907).

${ }^{64}$ Mass. Ann. Laws (r933) c. 244, § r2; W.Va. Code Ann. (Michie \& Sublett, r937) §37r2, held unconstitutional in Staud v. Sill, Ir 4 W.Va. 208, I7 I S.E. 428 (I933); Ga. L. (I935) pt. I, tit. VII, no. 4I2, § I. 